\title{
Organic rapeseed in Switzerland: 20 years of practice
}

\author{
Raphaël Charles ${ }^{1, *}$, Alice Baux ${ }^{2}$, Hansueli Dierauer ${ }^{3}$ and Claudia Daniel ${ }^{3}$ \\ ${ }^{1}$ Institut de recherche de l'agriculture biologique (FiBL), Lausanne, Switzerland \\ 2 Agroscope, Nyon, Switzerland \\ ${ }^{3}$ Forschungsinstitut für Biologischen Landbau (FiBL), Frick, Switzerland
}

Received 22 April 2020 - Accepted 6 October 2020

\begin{abstract}
Rapeseed is a major oilseed crop in Europe, whose development has been a roller coaster ride over the last 20 years. In a context of increasing demand for organic products, this crop must however face numerous constraints concerning its demanding place in the rotation, a choice of varieties limited to line varieties at least in the Switzerland, a crucial implantation which must cope with variable water stress during sowing and winters with less and less frost, very demanding nitrogen nutrition requirements in the context of organic farming, and particularly harmful pests. A consolidation of the research devoted to rapeseed cultivation, but also a redesign of its cropping system and economic considerations should make it possible to better position this crop in relation to agri-environmental contexts, but also in relation to the complementary aptitudes of other oilseed crops.
\end{abstract}

Keywords: rapeseed / oilseed crops / organic production

Résumé - Le colza bio en Suisse : 20 ans de pratiques. Le colza est une culture oléagineuse majeure en Europe, dont le développement s'est fait en dents de scie ces 20 dernières années. Dans un contexte de demande croissante en produits bio, cette culture doit toutefois faire face à de nombreuses contraintes qui concernent sa place exigeante dans la rotation, à un choix variétal limité aux variétés lignées du moins dans le contexte suisse, à une implantation cruciale qui doit composer avec des stress hydriques variables lors du semis et des hivers de moins en moins gélifs, à des besoins en nutrition azotée très exigeants dans le contexte de l'agriculture biologique, à des ravageurs particulièrement nuisibles. Une consolidation de la recherche consacrée à la culture du colza, mais également un re-design de son système de culture et des considérations économiques doivent permettre de mieux placer cette culture en fonction des contextes agri-environnementaux, mais également par rapport aux aptitudes complémentaires des autres cultures oléagineuses.

Mots clés : colza / cultures oléagineuses / production biologique

\section{Introduction}

The demand for organic rapeseed for use as edible oil is high. However, this crop is demanding. Several pests cause large variations in yield. The crop requires a lot of nitrogen for growth and therefore good soil quality for plant nutrition. The development of organic rapeseed followed the dynamics of organic farming in Switzerland. It was first developed for specific organic markets, in particular since 1998 on the initiative of a pioneering organic cooperative (Biofarm). It was then supported by the retail sector, which undertook to expand the range of organic products by offering organic rapeseed oil as of 2006. Ten years later, like many other production sectors, local production is subject to economic competition from imported products. Swiss organic rapeseed now covers a highvalue niche market that is not easily accessible to consumers who prefer cheap imported oils or other varieties of oil. This weak situation on the domestic market means that other crops that are likely to diversify and complete the coverage of needs for oilseeds need to be put into perspective, even though it is a question of analysing them from both an economic and an agronomic point of view.

Beyond the limits linked to the economic context, rapeseed remains a crop with a development potential that needs to be better defined, with an important position in conventional agriculture, but facing high technical challenges when it comes to conducting it in organic farming.

\footnotetext{
"Contribution to the Topical Issue "Organic foods in the oil \& protein crop supply chain / Le «Bio » dans la filière oléoprotéagineuse"

* Correspondance: raphael.charles@fibl.org
} 
While most field crops in organic agriculture mainly face disease, weed and nitrogen nutrition problems, oilseed rape, like potato, faces pressure from specific pests: pollen beetle (Meligethes aeneus), stem weevils (Ceutorhynchus ssp.), flea beetles (Psylliodes chrysocephalus) (Niggli et al., 2016). The analysis proposed here focuses on the successes and failures of this crop in the context of Swiss organic farming over the last 20 years. It examines its place in arable crop rotations, the key factors governing the success of its cultivation, research needs and development prospects.

\section{Method}

Several technical documents are made available for use in practice. Their content evolves according to feedback from practice and new knowledge. Their analysis allows to follow the evolution of practices in organic agriculture. Their crossreferencing with literature from conventional agriculture helps to situate the specific issues of organic farming. An analogous cross-reference with current scientific literature clarifies the evolution of the issues as well as persistent or new research needs.

A large part of the technical literature consulted comes from the website bioactualites.ch (cited in the text as references from practice), as well as from the fact sheets made available to farmers and advisors involved in organic or conventional farming (explicitly referenced).

\section{Position in the organic rotation}

Rapeseed is a demanding crop for its nutrition and is exposed to several pests during a relatively long growing period. The crop thrives especially on soils with high natural fertility. On farms with low or no livestock, its position in the crop rotation should be considered. As a rule, rapeseed should be placed at the beginning of the rotation in order to benefit from the regenerating effects of the grassland (compulsory in Switzerland at $20 \%$ of crop rotation). This favourable positioning in relation to the evolution and cycle of organic matter in the rotation is all the more important for farms without livestock (Fließbach et al., 2007). In terms of phytosanitary risk, rapeseed is seen more as a crop lightening the rotation compared to a significant presence of cereals. Crop rotation and landscape context are also interesting factors to take into account insofar as rapeseed flowering plays a major role in terms of biodiversity in arable crop regions, but also in reducing the exposure of rapeseed to a few pests that are causing the wide variation in rapeseed yield.

\section{Variety choice}

In spite of many challenges of this crop, rapeseed does not benefit from breeding specific for organic agriculture as wheat does (Messmer et al., 2015). Besides, the specifications of Bio Suisse (private label which covers almost the whole of organic production) for varietal selection include two basic principles that apply in particular to rapeseed (Bio Suisse, 2020). For all species, re-cultivable varieties are to be preferred. F1 hybrids are permitted, subject to restrictions for certain species.
For rapeseed, this means that hybrid varieties are prohibited as long as lines are available, except for high oleic low linolenic rapeseed, which is available exclusively as a hybrid variety. Since 2014 , in Switzerland, only restored hybrid varieties are included in the list of conventionally recommended varieties. Therefore, an evaluation of line varieties available in Europe was conducted under organic conditions. Varieties adapted to organic conditions were identified with high grain yield and good phoma tolerance (Luginbühl et al., 2017). Currently, two varieties are available and multiplied in Switzerland, Vision (2006) and Sammy (2012) (Dierauer and Klaiss, 2020). Sammy stands out in particular for its early flowering, which is appreciated when the pollen beetle pressure is high.

Part of the rapeseed production in Switzerland has also shifted to varieties richer in oleic acid (and lower in linolenic acid), which is more stable to heating than linoleic varieties. This production is under contract and organic production can also access it. Two varieties are currently available for conventional and organic production, V316OL and V350OL, restored hybrid varieties authorised in organic production for this specific production (Laurent et al., 2020).

\section{Sowing}

The sowing date mainly determines the state of development of the rapeseed at the beginning of winter and has to deal with two contradictory objectives depending on the availability of nitrogen: a limited growth to ensure physiological resistance to frost and physical resistance to snow, but a high biomass (number of leaves, size of the crown) favourable for the vegetation restart in spring. Despite the risks mentioned and thanks to breeding efforts to limit elongation before winter, the evolution of practices has shown a strong interest in early sowing in organic agriculture (as in conservation agriculture). Indeed, plant nutrition is highly dependent on the mineralization dynamics of soil organic matter and organic fertilizers. It generally does not benefit from substantial nitrogen residues from the previous crop like in conventional agriculture. Generally, an early sowing on a soil prepared accordingly accelerates favourably the speed of emergence of rapeseed, reduces its exposure time to seedling pests (slugs, flea beetles Psylliodes chrysocephala) when rapeseed is the most vulnerable. Indeed, after stage B4 (4 leaves), the risk is reduced even if rapeseed is exposed. For flea beetles and stem weevil, it is essential to have a strong biomass and, above all, a continuous growth from sowing to the end of winter. Indeed, when larvae are inside the stems, they can reach the plant apex and destroy it. But when the plant growth is dynamic and continuous, damages are reduced and even insignificant. Besides, this dynamic growth exerts a favourable pressure on weeds.

Although there is no consensus in practice, the issue of rapeseed overwintering benefits from useful scientific knowledge. Indeed, yield analysis places more emphasis on the fact that an optimal stand at the beginning of winter is a prerequisite for achieving a high level and stability of yield (Diepenbrock, 2000), despite the high compensation capacity of rapeseed (Sierts et al., 1987). On the other hand, winter risks mainly concern regions with continental climate, 
exposed to very low temperatures, whereas in regions with oceanic climate, this risk is reduced even further by climate change (Pullens et al., 2019). Crops at high altitudes (600$800 \mathrm{~m}$ above sea level) are also exposed by the risk associated with wintering.

\section{Plant nutrition}

The fertilisation of rapeseed must deal with numerous factors spanning several seasons. While $\mathrm{N}$ uptake is only slightly higher for rapeseed (156 kg N/ha) compared to winter wheat $(143 \mathrm{~kg} \mathrm{~N} / \mathrm{ha})$, the uptake dynamics are different (Sinaj et al., 2017). In the context of organic farming, a total manuring of $100 \mathrm{~kg} \mathrm{~N} /$ ha should be sufficient for a yield of $20-25 \mathrm{dt} / \mathrm{ha}$ (Daniel et al., 2017b). A difference of $30 \mathrm{~kg} \mathrm{~N} / \mathrm{ha}$ of nitrogen can be considered between a shallow soil ( $40 \mathrm{~kg} \mathrm{~N} / \mathrm{ha})$ and a deep soil $(70 \mathrm{~kg} \mathrm{~N} / \mathrm{ha})$ in terms of nitrogen available for rapeseed from the $\mathrm{N}$ residue at the end of winter and from humus mineralization (Michenau et al., 2016). The nature and quality of the soil therefore play a decisive role. However, the contribution of organic matter according to differences in soil quality remains poorly quantified in organic agriculture. Actually, no formal recommendation is made at present. However, the following considerations are highlighted.

Before winter, rapeseed needs are comparatively higher than those of wheat, but they can benefit from the potentially substantial mineralization peak at the end of summer. However, soil nitrogen availability may be reduced after a cereal crop or when rapeseed arrives only in the 3rd or 4th year after a grassland. Before sowing, a supply of solid manure is recommended during soil preparation, so as a supply of liquid manure or digestat after crop establishment.

At the end of winter, nitrogen must be absorbed before flowering. This early requirements, but also the reduced availability of readily available nitrogen in cold soil conditions make rapeseed more sensitive to soil quality and more demanding than wheat. Therefore, any fertilizer application, complementary to the fall supply, must be made as early as possible, counting on the earliest possible mineralization dynamics. These inputs are made in the form of farmyard fertilizers with a high proportion of available nitrogen, or/and commercially formulated to accelerate nutrient availability.

\section{Crop protection}

Weed control should be considered over the whole cultivation system. It is grown as a row crop for weed control in the autumn and as soon as winter comes to an end. The strong natural competition of this crop, if nitrogen availability is high at sowing and in autumn (Valantin-Morison and Meynard, 2008) generally facilitates weed control, which is not a major problem.

While diseases (Phoma lingam, Sclerotinia sclerotiorum) can be largely prevented by agronomic measures (rotation, choice of variety, sowing density), the numerous pests (slugs, flea beetles, stem weevils, pollen beetles, aphids) lead to great pressure on rapeseed, both in conventional and organic farming. In 2017 , while $60 \%$ of the conventional autumn wheat plots were managed according to the Extenso programme (which implies the withdrawal of insecticides, fungicides and growth regulators, in return for a premium per unit area), only $22 \%$ of the rapeseed plots were managed according to this programme (USP, 2018). The use of insecticides to control pests in autumn or spring therefore seems unavoidable for the major part of conventional growers, leading to an average of two insecticides being applied (de Baan et al., 2015). In practice, it appears that the assessment of the risks associated with different pests does not correspond to their effective damage. Thus, despite the actual risk, the stem weevil problem is overlooked and ignored due to the difficulty of its monitoring (Niggli et al., 2016). Conversely, pollen beetle invading the flower is feared because it is not only visible but also causes very apparent damage, although the effect is partly compensated.

The problem of pollen beetle is a perfect illustration of the means implemented by research and practice for the regulation of various pests. Some substances are known to be effective, but their use remains restrictive and excludes rapeseed. This is the case with spinosad, which is effective. However, this substance is not an option for the protection of rapeseed in organic farming, due to the harmful side effects on bees and other hymenoptera, and applications that should take place shortly before flowering (Niggli et al., 2016). Alternatives are therefore needed. In addition to preventive measures and natural extracts, various biotechnical methods have been tested for a long time with varying degrees of practical applicability (Daniel and Messerli, 2014): rock dust (Daniel and Dierauer, 2013; Daniel et al., 2017a), repellents (Daniel et al., 2018), entomopathogenic fungi (Kaiser et al., 2020), nematodes (Hokkanen, 2008), trap plants (Daniel and Messerli, 2014).

Trials in practice have shown that in favourable cases silicate rock dust (used as a plant fertilizer or adjuvant) decreased the number of pollen beetles by 50 to $80 \%$, leading to a more intensive flowering, a higher number of siliques and a yield increase of 23\% (Daniel et al., 2013). However, the effects were relatively variable and depended on rainfall. Similar effects on pollen beetles were obtained with kaolinclay, but with higher weather stability. These inert dusts are currently proposed as a preventive measure (Daniel and Messerli, 2014) and are the subject of a specific recommendation for practice (Daniel et al., 2017a). The effect of manure is also observed by farmers with a reduction in the number of pollen beetles on flower buds. However broad surface application of liquid manure is no longer justifiable due to the resulting ammonia losses.

Therefore, the ability of rapeseed plants to compensate for pollen beetles damage to the flower buds on the main stems is an important factor justifying early sowing and generous manuring. However, intensifying nitrogen fertilization to solve phytosanitary problems is a nonsense, so that only biological pest control solutions can make rapeseed cultivation more accessible (Niggli et al., 2016). Varietal differences in plant plasticity could also be considered (Pinet et al., 2015).

The landscape context plays a role with different noncongruent processes from which it is difficult to extract the predominance of one or the other factor. The pest situation is rather critical in the context of rather small plots in organic agriculture, respectively in areas where non-organic rapeseed may be very common (Daniel et al., 2016; Dierauer et al., 2011). Paradoxically, high biodiversity of organic farms may 
reduce the dominance of a specific pest and may favour beneficial organisms, natural environments or rapeseed plots from the previous year constitute reservoirs. Thus, large rapeseed plots are effectively less affected by the various pests, if not on their edges. The stem weevil, which overwinters in the soil, takes advantage of any nearby context to invade new crops. On the other hand, open and windy sites seem to be less exposed to the recurrent problems of pollen beetle. This insect is able to distinguish the phenological stages of rapeseed, which can be used in a push-pull strategy (Cook et al., 2007) by concentrating the pollen beetle on trap plants or in one area (Daniel and Messerli, 2014). The establishment of trap strips of very early flowering rape or rapeseed (pull) can be supplemented by the use of rock dust on the plot (pull).

Finally, a new strategy is to make rape fields undetectable by the application of strongly odorous or repellent substances. In 2013, various affordable essential oils were tested for their repellent effect, the most efficient being mint oil and citronella oil (Daniel, 2015). Since 2014, the formulation of field-usable flavours is under development. The aim is to ensure that the diffusion of the active ingredients takes place over a period of at least three weeks by biocompatible dispensers, only when weather conditions are favourable ( $\operatorname{sun}, 15-23^{\circ} \mathrm{C}$ ), the active substance being protected otherwise (Daniel et al., 2018). In comparison with untreated plots, prototypes tested between 2017 and 2019 in the field showed a significant reduction in attacks and a $20-25 \%$ higher number of siliques on the main stem. Optimal positioning of the dispensers in the growing vegetation as well as easy and quick handling were the subject of work in 2019 that allows large-scale field trials in 2020. In the same perspective, co-formulation developments between Beauveria bassiana spores and known natural effective substances (rock dust, rapeseed oil emulsion) have been conducted to make the fungus more efficient against pollen beetle (Kaiser et al., 2020).

\section{Cropping system re-design}

The intensive protection of rapeseed $(1.5$ herbicide and 2 insecticides, 1 fungicide) (de Baan et al., 2015) and the high $\mathrm{N}$ requirements $(150 \mathrm{~kg} / \mathrm{ha}$ recommended in conventional agriculture, Sinaj et al., 2017), as well as the general difficulties encountered in organic farming have led to the development of alternative cultivation methods. The sowing of companion plants to rapeseed was initiated in conservation agriculture (to deal with weeds and nitrogen) and currently it aims to provide various ecosystem services more broadly: competition against weeds, pest regulation, improvement of nitrogen use efficiency (Cadoux et al., 2015). Even if its effectiveness remains partial, this technique was very quickly adopted by growers and supported by extension. Significant effects have been scientifically verified on weeds (Lorin et al., 2015) and nitrogen nutrition in rapeseed (Lorin et al., 2016), but have been modest on grasses, and uncertain for pest control. Technical adjustments, developed empirically, have continued in the choice of companion plants to take into account the competitiveness of companion plants based on their winter hardiness or seed set in autumn (Courtois, 2019). Progress has also continued in the regulation of autumn pests such as flea beetles and terminal bud weevils (Breitenmoser et al., 2020).
Evolution des surfaces de cultures oléagineuses

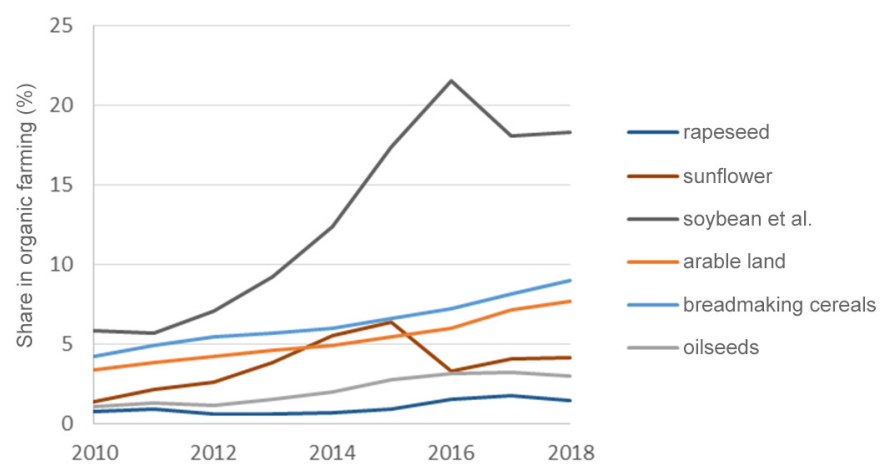

Fig. 1. Development of the share of organically cultivated areas for oilseed crops in Switzerland. Agristat USP data.

\section{Economic considerations}

In a worldwide perspective, organic oilseeds constitute an important element in organic production. The demand for feedstuffs and for human consumption is still growing. About 1.5 million hectares, corresponding to $11 \%$ of the worlds organic arable land, were used for growing organic oilseeds in 2018 (Willer et al., 2020). But this is only $0.6 \%$ of the world's total oilseed area. Soybean occupies half of this area and a third of the oilseeds are produced in China, mainly for export. It is expected that the area under organic soybean will continue to grow strongly.

In Europe, oilseeds grown in organic agriculture represent $1.4 \%(2.5 \%$ for the EU) of the oilseed area (Willer et al., 2020). Of the 499'000 ha of organic oilseeds cultivated in 2018, soybean covered 170'000 ha, sunflower 142'000 ha and rapeseed 86'000 ha. In Switzerland, the proportion of open land under organic cultivation increased from $3.4 \%$ in 2010 to $7.7 \%$ in 2018 and the proportion of rapeseed from $0.7 \%$ to $1.4 \%$. In 2018 , the organic share of sunflowers was $4.2 \%$ and that of other oilseeds, including soya, $18 \%$ (Fig. 1). The low presence of rapeseed in the organic crop rotation in Switzerland can be explained by two main factors: the difficulty of producing this species organically and the state of the markets.

In Europe, the relative yield gap between organic and conventional production varies for oilseeds from nonsignificant to $26 \%$ according to meta-analyses (Niggli et al., 2016). In Switzerland, the average yield of rapeseed is $3.5 \mathrm{t} / \mathrm{ha}$ in conventional (average 2016-2018 according to USP, 2019), but is much lower in organic, varying between 1.5 and $3.0 \mathrm{t} / \mathrm{ha}$. It is clear that today rapeseed cultivation is practically impossible in areas with a high pest presence. For similar reasons, its cultivation is also avoided on organic farms growing cruciferous vegetables (Daniel et al., 2016).

This plant-health constraint leads to the cultivation of other oilseeds. Thus, sunflower is proportionally more cultivated organically $(60 \%$ of the rapeseed area) than conventionally (24\%) (USP, 2019). Sunflower cultivation can satisfy modest cultivation requirements that are more in line with the conditions of organic farming (Dierauer and Kessler, 2014). Nitrogen requirements are limited with $60 \mathrm{~kg} \mathrm{~N} / \mathrm{ha}$ largely covered by soil supply. Plant-health risks concern mildew, 
which can be prevented by the sanitary quality of the seed, and aphids, which cause only limited damage. Other mainly hardy oilseed crops such as camelina and flax are also grown, mainly for niche markets.

Beyond the identified agronomic impasse, several economic factors explain the limited development of organic rapeseed. With a national self-sufficiency rate ranging between $50 \%$ and $60 \%$ (OFAG, 2016), reaching nearly $90 \%$ of the $38,000 \mathrm{t}$ of refined rapeseed oil consumed and less than $10 \%$ of the 48,000 t of sunflower (Perrin, 2016), the implementation of any new production must have a significant added value, including in the range of organic products. For many years, conventional rapeseed oil benefits from a particularly welldeveloped chain (specification of uses, labels, visibility including in processing and catering), which broad success does not encourage the development of an organic rapeseed oil chain.

Like the relative areas in Europe, the development of oilseeds in Switzerland currently also concerns soybeans, which are expected to be used for two purposes. On the one hand, the demand for local plant protein for human consumption is increasing. On the other hand, the specifications of Bio Suisse require that from 2022 onwards all concentrated fodder for ruminants be covered by national organic production. On the other hand, the price difference between Swiss production and imports from Eastern Europe is too great to allow a rise in the production of sunflower oil, of for which the added value for the consumer is less tangible.

\section{Conclusion}

De facto, the development of organic agriculture is not a copy-paste of mainstream conventional productions. Oilseeds and rapeseed in particular are currently limited in Switzerland, but the factors that could make this crop more common in organic farming are known. In terms of plant protection, more effective pest control would allow a substantial breakthrough in order to better exploit the high yield potential of this crop. Adaptation of the crop to the extensive soil conditions and in particular better use of nitrogen would complement farmers' efforts to improve soil quality and to become more self-sufficient with regard to the import of fertilizers. This would make it possible to develop rapeseed also in low-potential soils, with a high autonomy level in terms of inputs, but finally with a competitive profitability. Despite a significant price differential compared to imported oils, further joint development of the market for organic and local products should lead to a wider use of rapeseed in processed products with a national designation as well as for direct consumption. Similarly, rapeseed and arable crop rotations could benefit from continued pressure to ensure consistency between the diversity of production on organic farms and that of products labelled at the point of sale.

\section{References}

Bio Suisse. 2020. Cahier des charges pour la production, la transformation et le commerce des produits Bourgeon (online). Basel: Bio Suisse.
Breitenmoser S, Steinger T, Hiltpold I, et al. 2020. Des plantes associées au colza pour contrôler les adultes d'altises, un insecte ravageur. Recherche agronomique suisse 11: 11-16.

Cadoux S, Sauzet G, Valantin-Morison M, et al. 2015. Intercropping frost-sensitive legume crops with winter oilseed rape reduces weed competition, insect damage, and improves. OCL 22: D302.

Cook SM, Khan ZR, Pickett JA. 2007. The use of push-pull strategies in integrated pest management. Annu Rev Entomol 52: 375-340.

Courtois N. 2019. Colza associé, cultivez votre désherbant. Fiche technique. Genève: Agrivulg.

Daniel C, Dierauer H. 2013. Steinmehl zur Regulierung des Rapsglanzkäfers Meligethes spp. Bonn: Wissenschaftstagung Ökologischer Landbau, Rheinische Friedrich-Wilhelms-Universität.

Daniel C, Dierauer H, Clerc M. 2013. The potential of silicate rock dust to control pollen beetles (Meligethes spp.). IOBC-WPRS Bulletins 96: 47-55.

Daniel C, Messerli N. 2014. Méligèthes du colza. Fiche technique 1484 (en ligne). Frick: Institut de recherche de l'agriculture biologique (FiBL).

Daniel C. 2015. Ätherische Öle als Repellentien gegen den Rapsglanzkäfer (Meligethes spp., Coleoptera: Nitidulidae). Mitteilungen der Deutschen Gesellschaft für allgemeine und angewandte Entomologie 20: 213-216.

Daniel C, Collier R, Thomas J, Hommes M. 2016. Effects of landscape and region on pests and pathogens in Brassica vegetables and oilseed rape. IOBC-WPRS Bulletin 118: 99-105.

Daniel C, Conder M, Weidmann G. 2017a. Use of rock dust against the rape pollen beetle. Practice Abstract, No. 032. Frick: Research Institute of Organic Agriculture (FiBL).

Daniel C, Dierauer H, Clerc M, Conder M, Weidmann G. 2017b. Nitrogen supply for winter oilseed rape. OK-Net Arable Practice Abstract, No. 009. Frick: Research Institute of Organic Agriculture (FiBL).

Daniel C, Raderschall C, Cahenzli F. 2018. Formulierungen von ätherischen Ölen zur Regulierung des Rapsglanzkäfers (Meligethes spp.). Mitteilungen der Deutschen Gesellschaft für allgemeine und angewandte Entomologie 21: 153-156.

de Baan L, Spycher S, Daniel O. 2015. Utilisation des produits phytosanitaires en Suisse de 2009 à 2012. Recherche agronomique suisse 6: 48-55.

Diepenbrock W. 2000. Yield analysis of winter oilseed rape (Brassica napus L.): a review. Field Crops Research 67: 35-49.

Dierauer H, Klaiss M. 2020. Liste variétale cultures fourragères et grandes cultures (sauf céréales et pommes de terre). Fiche technique 1373 (en ligne). Frick: Institut de recherche de l'agriculture biologique (FiBL).

Dierauer H, Daniel C, Humphrys C, Hebeisen T. 2011. Bioraps, Merkblatt 1343 (online). Frick: Forschungsinstitut für biologischen Landbau (FiBL).

Dierauer H, Kessler HG. 2014. Biosonnenblumen, Merkblatt 1097 (online). Frick: Forschungsinstitut für biologischen Landbau (FiBL).

Fließbach A, Oberholzer HR, Gunst L, Mäder P. 2007. Soil organic matter and biological soil quality indicators after 21 years of organic and conventional farming. Agriculture, Ecosystems \& Environment 118: 273-284.

Hokkanen HMT. 2008. Biological control methods of pest insects in oilseed rape. EPPO Bulletin 38: 104-109.

Kaiser D, Handschin S, Rohr RP, Bacher S, Grabenweger G. 2020. Co-formulation of Beauveria bassiana with natural substances to control pollen beetles - Synergy between fungal spores and colza oil. Biological Control 140: 104-106. 
Laurent E-A, Nussbaum V, Strahm S, Baux A. 2020. Liste recommandée des variétés de colza d'automne pour la récolte 2021. Agroscope Transfer 316: 1-2.

Lorin M, Jeuffroy M-H., Butier A, Valantin-Morison M. 2015. Undersowing winter oilseed rape with frost-sensitive legume living mulches to improve weed control. European Journal of Agronomy 71: 96-105.

Lorin M, Jeuffroy M-H., Butier A, Valantin-Morison M. 2016. Undersowing winter oilseed rape with frost-sensitive legume living mulch: consequences for cash crop nitrogen nutrition. Field Crops Research 193: 24-33.

Luginbühl C, Baux A, Hiltbrunner J, Nussbaum V. 2017. Forschung für die ideale Biorapssorte. 4. Nationale Ackerbautagung. 23. Januar, Murten: Ed. Agridea, pp. 21-18.

Messmer M, Wilbois K-P, Baier C, et al. 2015. Plant breeding techniques, an assessment for organic farming. Frick: Research Institute of Organic Agriculture (FiBL).

Michenau A, Champolivier L, Courtois N, Sinaj S, Baux A. 2016. Réglette azote colza : adaptation pour la Suisse d'un outil d'aide à la fertilisation azotée du colza. Recherche agronomique suisse 7: 378-383.

Niggli U, Schmidt J, Watson C, et al. 2016. Organic Knowledge Network Arable - D.3.1 state-of-the-art research results and best practices. Frick: Research Institute of Organic Agriculture (FiBL).

OFAG. 2016. Fiche d'information sur la sécurité alimentaire. No. 1 : taux d'auto-approvisionnement (online). Bern: Office fédéral de l'agriculture (OFAG).
Perrin PY. 2016. L'huile de colza... un atout pour la santé (online). Bern: Fédération suisse des producteurs de céréales (FSPC).

Pinet A, Mathieu A, Jullien A. 2015. Floral bud damage compensation by branching and biomass allocation in genotypes of Brassica napus with different architecture and branching potential. Frontiers in Plant Science 6: 70. DOI: 10.3389/ fpls.2015.00070.

Pullens JWM, Sharif B, Trnka M, Balek J, Semenov MA, Olesen JE. 2019. Risk factors for European winter oilseed rape production under climate change. Agricultural and Forest Meteorology 72-273: 30-39.

Sierts H-P, Geisler G, Leon J, Diepenbrock W. 1987. Stability of yield components from winter oil-seed rape (Brassica napus L.). Journal of Agronomy and Crop Science 158: 107-113.

Sinaj S, Charles R, Baux A, et al. 2017. 8. Fertilisation des grandes cultures. Recherche agronomique suisse 8: 8/1-8/46.

USP. 2018. Agristat 18-06. Cahier statistique mensuel. Brugg: Union suisse des paysans.

USP. 2019. Statistiques et évaluations concernant l'agriculture et l'alimentation 2019, chapitre 02 - Production végétale (online). Brugg: Union suisse des paysans.

Valantin-Morison M, Meynard JM. 2008. Diagnosis of limiting factors of organic oilseed rape yield. A survey of farmers' fields. Agronomy for Sustainable Development 28: 527-539.

Willer H, Travnicek J, Schlatter B. 2020. Current status of organic oilseeds worldwide - statistical update. OCL 27: 62.

Cite this article as: Charles R, Baux A, Dierauer H, Daniel C. 2020. Organic rapeseed in Switzerland: 20 years of practice. OCL 27: 68. 